\title{
Notes on the vocalizations of Yellow-breasted Boatbill (Machaerirhynchus flaviventer)
}

\section{Peter Boesman}

In the following we briefly analyze and compare voice of the different races of Yellowbreasted Boatbill (Machaerirhynchus flaviventer). We also try to quantify the extent of any vocal differences using the criteria proposed by Tobias et al. (2010), as a support for taxonomic review. We have made use of sound recordings available on-line from Xeno Canto (XC) and Macaulay Library (ML).

Typical song phrase is a combination of a burry/buzzy whistle or rattling series and some crisp staccato notes, sometimes in stuttered series. Song in Australia is slightly more variable than in New Guinea, some Australian song phrases being quite different, but others very similar to those in New Guinea.

Some examples:

Australia

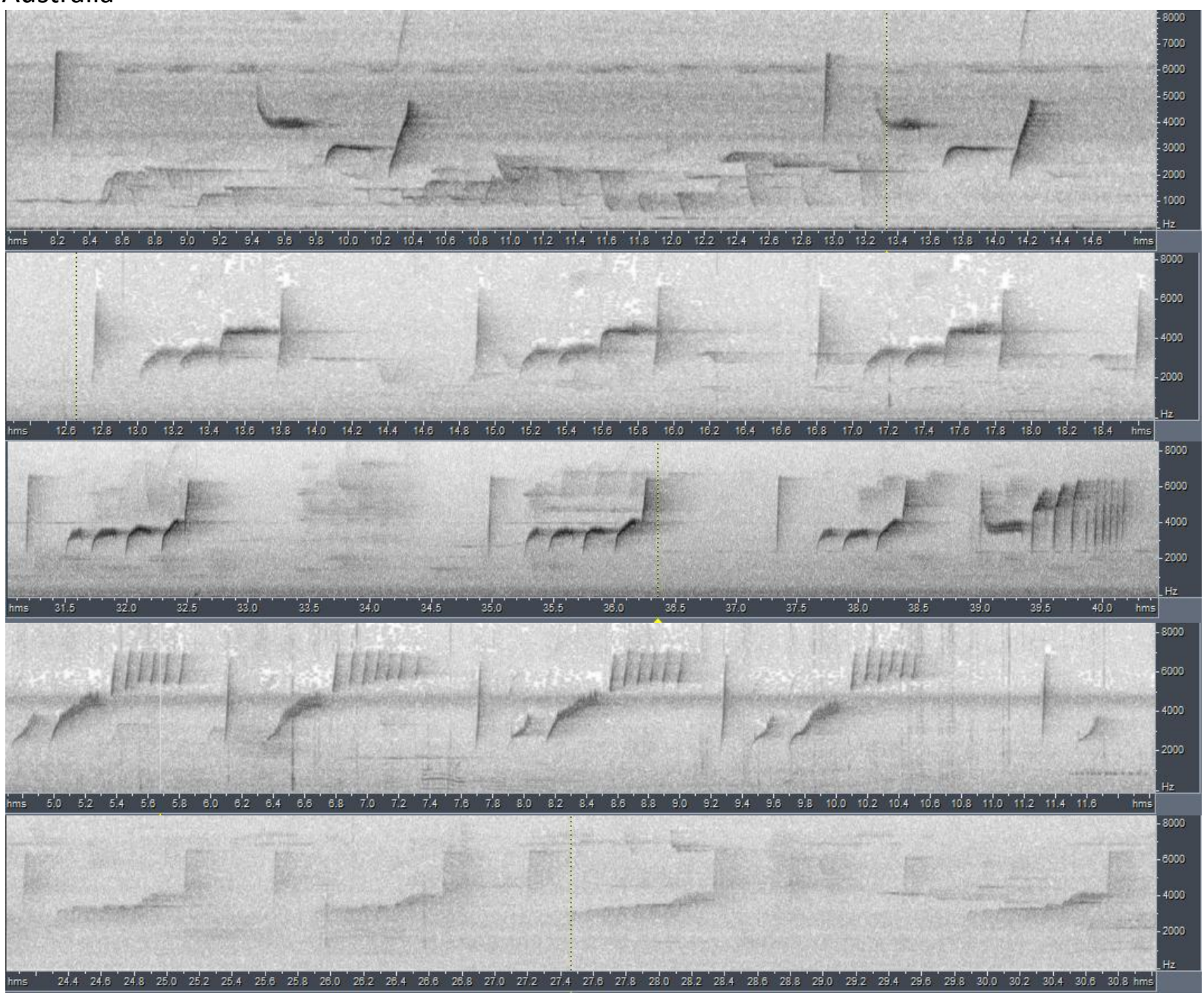



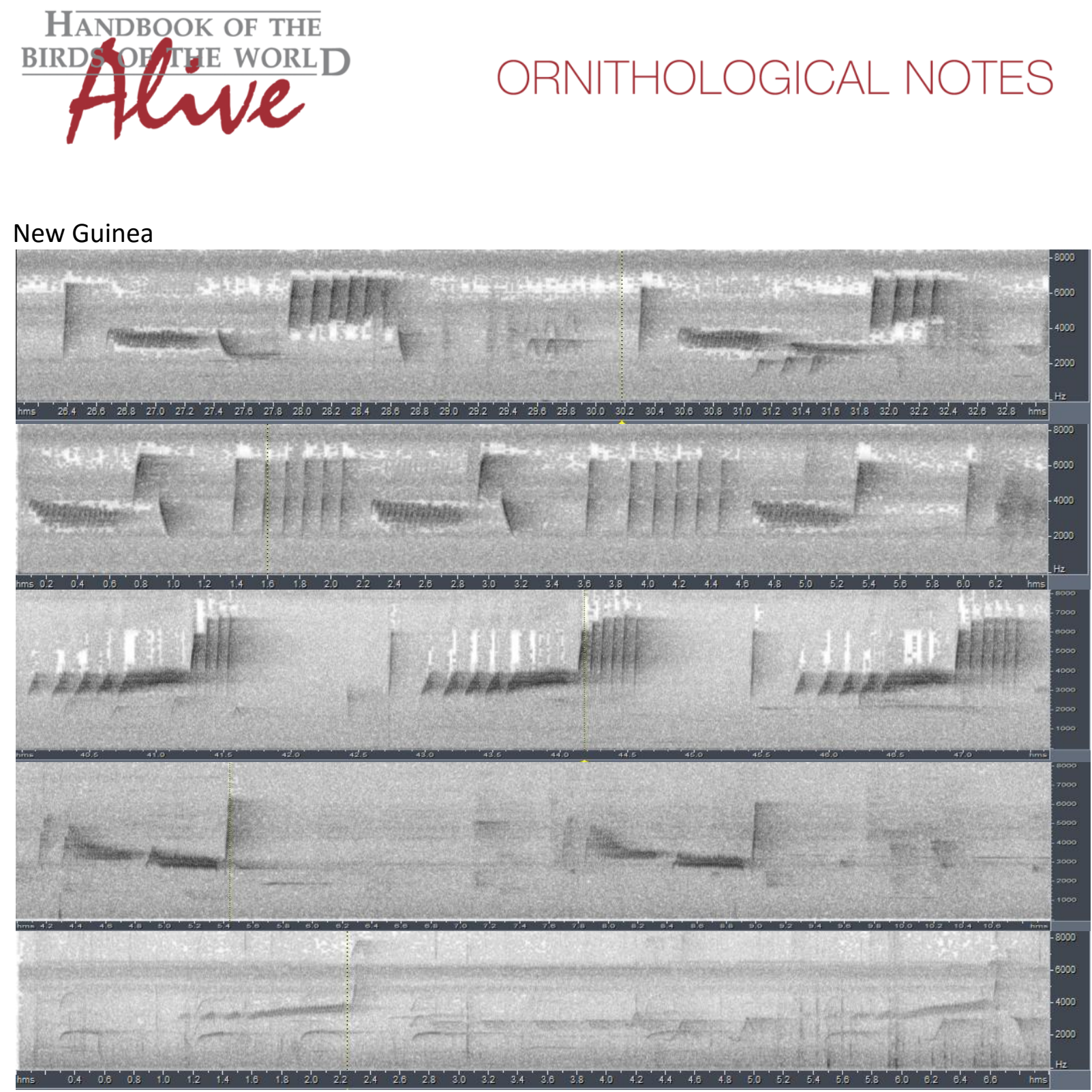

Basic sound parameters such as frequency range, $\mathrm{min} / \mathrm{max}$. frequency, note length, phrase length etc. are all rather similar.

Given the degree of variation, we have not found any clear differences between birds of New Guinea and Australia (which form morphologically two distinct groups). A much larger set of recordings would be needed to prove any statistically significant differences, but it can be expected that at most this will lead to a minor vocal score when applying Tobias criteria.

This note was finalized on 16th November 2015, using sound recordings available on-line at that moment. We would like to thank in particular the sound recordists who placed their recordings for this species on XC and ML: Marc Anderson, Nick Athanas, Scott Connop, Fernand Deroussen, Phil Gregory, Emma Greig, Henk Krajenbrink, Linda Macaulay, Andrew Mack, Eliot Miller, John V Moore, Frank Rheindt and Marc Robbins.

\section{References}

Tobias, J.A., Seddon, N., Spottiswoode, C.N., Pilgrim, J.D., Fishpool, L.D.C. \& Collar, N.J. (2010). Quantitative criteria for species delimitation. Ibis 152(4): 724-746. 


\section{Recommended citation}

Boesman, P. (2016). Notes on the vocalizations of Yellow-breasted Boatbill

(Machaerirhynchus flaviventer). HBW Alive Ornithological Note 182. In: Handbook of the Birds of the World Alive. Lynx Edicions, Barcelona. (retrieved from

http://www.hbw.com/node/932119 on 24 August 2016). 